УДК 349.2

DOI https://doi.org/10.32849/2663-5313/2020.2.24

\title{
Тетяна Жовнір,
}

аспірант кафедри трудового права

Національного юридичного університету імені Ярослава Мудрого

\section{СПІВВІДНОШЕННЯ ПОНЯТТЯ «САМОЗАЙНЯТА ОСОБА» 3 ІНШИМИ СУМІЖНИМИ ПРАВОВИМИ КАТЕГОРІЯМИ}

Стаття присвячена удосконаленню підходів до визначення категорії «самозайнята особа» як суб'єкта права шляхом виявлення ї̈ найбільш суттєвих правових ознак. Уконтексті наведеного актуалізовано науково-теоретичну проблематику щодо розмежування поняття «самозайнята особа» 3 іншими суміжними правовими категоріями. Наголошено на недостатній теоретичній розробленості наведеного поняття, внаслідок чого досить часто відбувається ототожнення зазначеного поняття з іншими подібними нормативно-правовими та науково-теоретичними поняттями. У зв'язку з наведеним автором запропоновано власний підхід до розмежування і співвідношення поняття «самозайнята особа» $з$ поняттями «фізична особа», «фізична особа-підприємеиь», «юридична особа», «особа, яка уповноважена на виконання функиій держави». Наголошено, що певною мірою мають подібні правові характеристики такі поняття, як самозайнята особа та юридична особа, які слід дослідити. Отже, спільними правовими рисами понять «самозайнята особа» та «юридична особа» $\epsilon$ таке: $і$ самозайнята, і юридична особа є суб'єктами правовідносин; і самозайнята, і юридична особа можуть провадити незалежну та самостійну, здійснювану на власний ризик та з метою отримання прибутку підприємницьку діяльність, а також виконувати місіонерську місію, досягати певних соиіальних, культурних та інших цілей; набуття правосуб'єктності як юридичною, так і самозайнятою особою пов'язане з державною реєстрачією, а також у певних випадках з отриманням відповідної лічензї; як самозайнята, так і юридична особи можуть виступати роботодавием, бути страхувальником. Зроблено висновок, що натепер нечіткість нормативно-правових меж між різними, подібними до поняття «самозайнята особа» правовими категоріями зумовлена насамперед не ӥхнвою первинною суспільною, економічною і соиіальною природою, а недосконалістю чинного законодавства. Надалі чинне нормативно-правове регулювання зазначеного питання повинне розвиватися у напрямі уточнення основних правових ознак поняття «самозайнята особа», кристалізації і уніфікації підходів до ї̈ відмежування від інших подібних правових категорій, а також розробки иілісного правового інституту, який регулюватиме усі аспекти функиіонування такого важливого суб'єкта правовідносин, насамперед ї̈ діяльність, як суб'єкт права сочіального забезпечення.

Ключові слова: самозайнята особа, фізична особа, фізична особа-підприємець, юридична особа, особа, яка уповноважена на виконання функцій держави, страхувальник.

Постановка проблеми. Натепер поняття «самозайнята особа» є досить колізійним, та з приводу його чіткого визначення існують суперечності і численні дискусії. Зазначене поняття нині не є усталеним, його вичерпні правові характеристики потребують уточнення та деталізації, конструктивного осмислення й аналізу. У зв'язку з цим досить частими є випадки ототожнення зазначеного поняття 3 іншими подібними нормативноправовими та науково-теоретичними поняттями, нечіткість розуміння та трактування досліджуваної категорії. Тому дуже велике теоретичне і практичне значення має розмежування поняття «самозайнята особа» з іншими суміжними правовими категоріями.

Аналіз останніх досліджень і публікацій. Окремі питання проблем правового регулю- вання правового статусу та діяльності самозайнятих осіб досліджували Д. А. Бекерська, Л. К. Воронова, О. С. Вишневецький, Д. А. Кобильнік, В. М. Небильцова, Н. В. Остапенко та інші вчені. Поряд із цим у сучасній юридичній науці не проведено чіткого розмежування поняття «самозайнята особа» з іншими суміжними правовими категоріями.

Метою даної статті $є$ проведення розмежування поняття «самозайнята особа» 3 іншими суміжними правовими категоріями.

Виклад основного матеріалу. Насамперед доцільно з'ясувати особливості співвідношення поняття «самозайнята особа» 3 поняттям «фізична особа». Відповідно до Цивільного кодексу України від 16.01.2003 № 435-IV, людина як учас- 
ник цивільних відносин вважається фізичною особою. Здатність мати цивільні права та обов'язки (цивільну правоздатність) мають усі фізичні особи. Цивільна правоздатність фізичної особи виникає у момент iï народження. Цивільна правоздатність фізичної особи припиняється у момент їі смерті. Повну цивільну дієздатність має фізична особа, яка досягла вісімнадцяти років (повноліття). Фізична особа набуває прав та обов'язків і здійснює іх під своїм ім'ям. Ім'я фізичної особи, яка є громадянином України, складається із прізвища, власного імені та по батькові, якщо інше не випливає із закону або звичаю національної меншини, до якої вона належить [1]. За Законом України «Про державну реєстрацію юридичних осіб, фізичних осіб-підприємців та громадських формувань» від 15.05.2003 №755-IV, в Сдиному державному реєстрі містяться такі відомості про фізичну особу-підприємця: 1) прізвище, ім'я, по батькові; 2) дата народження; 3) реєстраційний номер облікової картки платника податків або серія та номер паспорта (для фізичних осіб, які через свої релігійні переконання відмовилися від прийняття реєстраційного номера облікової картки платника податків, повідомили про це відповідний контролюючий орган і мають відмітку в паспорті про право здійснювати платежі за серією та номером паспорта); 4) країна громадянства; 5) місцезнаходження (місце проживання або інша адреса, за якою здійснюється зв'язок з фізичною особою-підприємцем); 6) види діяльності; 7) дата та номер запису в Сдиному державному реєстрі; 8) інформація для здійснення зв'язку з фізичною особою-підприємцем: телефон та адреса електронної пошти; 9) підстави для зупинення розгляду документів; 10) інформація про направлення повідомлення правоохоронним органам у разі виникнення сумнівів щодо справжності поданих документів; 11) підстави для відмови у державній реєстрації; 12) дата прийняття, дата набрання законної сили та номер судового рішення, на підставі якого проведено реєстраційну дію; відомості про ліцензування виду господарської діяльності суб'єкта господарювання та інші відомості [2]. А згідно із Законом України «Про нотаріат» від 02.09.1993 № 3425-XII, реєстрація приватної нотаріальної діяльності провадиться Головним управлінням юстиції Міністерства юстиції України в Автономній Республіці Крим, головними управліннями юстиції в областях, містах Києві та Севастополі на підставі заяви особи, яка має свідоцтво про право на зайняття нотаріальною діяльністю, та акта про сертифікацію про відповідність робочого місця (контори) приватного нотаріуса встановленим цим Законом умовам. У заяві зазначається назва нотаріального округу, в якому особа буде займатися нотаріальною діяльністю. Робоче місце (контора) приватного нотаріуса повинно розташовуватися в межах визначеного для нього нотаріального округу. Вимоги до робочого місця (контори) приватного нотаріуса встановлюються Міністерством юстиції України. Приватний нотаріус має печатку із зображенням Державного Герба України, яка містить слова «приватний нотаріус», його прізвище, ім'я та по батькові, назву нотаріального округу [3].

Враховуючи і наведені норми, і загальні положення наукової доктрини, доцільно відзначити, що поняття «фізична особа» та «самозайнята особа» мають як спільні, так і відмінні риси. Спільними правовими ознаками понять, що аналізуються, є: 1) і фізична, і самозайнята особа за своєю правовою сутністю - це людина як учасник правовідносин; 2) у правовідносинах і фізична, і самозайнята особа виступають від власного імені, яке складається з прізвища, імені та по-батькові, які надаються згідно із законом; 3) правосуб'єктність самозайнятої особи є складовою частиною правосуб'єктності фізичної особи; 4) категорія «самозайнята особа» є спеціальним правовим статусом фізичної особи.

Поряд із цим наведені поняття є різними, а тому мають окремі відмінні правові характеристики: 1) різними є момент і підстави набуття правосуб'єктності фізичною та самозайнятою особами: правосуб'єктність фізичної особи складається 3 частин: правоздатності, дієздатності та деліктоздатності Правоздатність наступає 3 моменту народження, а настання відповідних обсягів дієздатності і деліктоздатності пов'язане із досягненням визначеного законодавством віку, одруженням або наданням дієздатності Своєю чергою, набуття правосуб'єктності самозайнятою особою пов'язане 3 однією з таких необхідних умов або певної їх комбінації: державна реєстрація, отримання відповідного свідоцтва про право на зайняття незалежною професійною діяльністю, реєстрація в уповноваженому органі, отримання ліцензії; 2) різні правові характеристики місцезнаходження наведених осіб: місцем проживання фізичної особи є житло, у якому вона проживає постійно або тимчасово, щодо самозайнятої особи, то важливою правової характеристикою іiї правового статусу $є$ її місцезнаходження, яке не завжди є тотожним місцю проживання. В окремих випадках до такого місцезнаходження законодавством 
встановлені окремі вимоги щодо характеристик робочого місця, його знаходження в межах певного округу, адміністративнотериторіальної одиниці, обладнання, надання реквізитів для державної реєстрації. Місцезнаходження розглядається як засіб зв'язку з самозайнятою особою; 3) поняття «фізична особа» є універсальним та позначає людину як учасника будь-якого виду галузевих правовідносин, тоді як поняття «самозайнята особа» визначає особливий правовий статус, якого набула фізична особа і який відображає іï як учасника насамперед правовідносин, пов'язаних із господарською та незалежною професійною діяльністю; 4) самозайнята особа за одним своїм видом господарської або незалежної професійної діяльності може виступати одночасно у статусі роботодавця і працівника, страхувальника і застрахованої особи, тоді як фізична особа за одним із видів своєї трудової діяльності може бути або роботодавцем та страхувальником, або працівником та застрахованою особою; 5) презюмується, що самозайнята особа за своїм правовим статусом належить до зайнятого населення, тоді як фізична особа може бути як зайнятою, так і безробітною.

Надалі розмежуємо такі подібні поняття, як фізична особа-підприємець та самозайнята особа: 1) поняття «самозайнята особа» та «фізична особа-підприємець» співвідносяться між собою як ціле та частина, більш загальне та конкретне відповідно; 2) фізична особа-підприємець провадить діяльність, пов'язану з отриманням доходу, яку здійснюе на власний ризик та систематично, своєю чергою поняття «самозайнята особа» позначає, крім фізичних осіб-підприємців, осіб, які провадять незалежну професійну діяльність, діяльність, яка може бути спрямована на досягнення інших, не пов'язаних з отриманням прибутку (соціальних, професійних, культурних, мистецьких, наукових та інших) цілей; 3) поняття «фізична особа-підприємець» відображає фізичну особу як суб'єкта підприємництва та господарювання, тоді як поняття «самозайнята особа» є більш широким та застосовується в тому числі для цілей законодавства про зайнятість населення, податкового законодавства, а також законодавства про соціальне забезпечення. Слушною у цьому аспекті є думка Д. І. Сірохи про те, що звуження кола роботодавців шляхом використання на законодавчому або науковому рівні для характеристики категорії «роботодавець» лише термінів «наймач» чи «підприємець»є недоцільним, бо ці поняття неточно відображають зміст статусу суб'єкта трудових правовідносин, крім того, фізична особа-підприємець необов'язково вико- ристовує найману працю, оскільки може здійснювати трудову діяльність самостійно [4, c. 438].

Доцільно зауважити, що певною мірою мають подібні правові характеристики такі поняття, як самозайнята особа та юридична особа, які слід дослідити. Отже, спільними правовими рисами понять «самозайнята особа» та «юридична особа» є таке: 1) і самозайнята, і юридична особа є суб'єктами правовідносин; 2) і самозайнята, і юридична особа можуть провадити незалежну та самостійну, здійснювану на власний ризик та 3 метою отримання прибутку підприємницьку діяльність, а також виконувати місіонерську місію, досягати певних соціальних, культурних та інших цілей; 3) набуття правосуб'єктності як юридичною, так і самозайнятою особою пов'язане $з$ державною реєстрацією, а також у певних випадках з отриманням відповідної ліцензії; 4) як самозайнята, так і юридична особи можуть виступати роботодавцем, бути страхувальником.

Водночас це якісно відмінні поняття, які не слід плутати та необхідно чітко розмежовувати. Юридичною особою є організація, створена і зареєстрована у встановленому законом порядку. Юридичні особи можуть створюватися у формі товариств, установ та в інших формах, встановлених законом. Товариством є організація, створена шляхом об'єднання осіб (учасників), які мають право участі у цьому товаристві. Товариство може бути створено однією особою, якщо інше не встановлено законом. Товариства поділяються на підприємницькі та непідприємницькі. Установою є організація, створена однією або кількома особами (засновниками), які не беруть участі в управлінні нею, шляхом об'єднання (виділення) їхнього майна для досягнення мети, визначеної засновниками, за рахунок цього майна. Для створення юридичної особи іï учасники (засновники) розробляють установчі документи, які викладаються письмово і підписуються всіма учасниками (засновниками), якщо законом не встановлений інший порядок їх затвердження. Юридична особа повинна мати своє найменування, яке містить інформацію про іiї організаційно-правову форму та назву. Найменування установи має містити інформацію про характер її діяльності. Юридична особа може мати, крім повного найменування, скорочене. Юридична особа набуває цивільних прав та обов'язків і здійснює їх через свої органи, які діють відповідно до установчих документів та закону. Місцезнаходженням юридичної особи є фактичне місце ведення діяльності чи розташування офісу, з якого 
проводиться щоденне керування діяльністю юридичної особи (переважно знаходиться керівництво) та здійснюється управління й облік [1].

Таким чином, відмінними правовими рисами зазначених категорій є: 1) юридична особа $є$ новоствореною правовою субстанцією, організацією, яка існує та функціонує окремо, володіє певним майном та обсягом правосуб'єктності, тоді як функціонування самозайнятої особи не пов'язане зі створенням нової особи - це фізична особа, яка вже існує, наділена правосуб'єктністю та вже діє як учасник правовідносин; 2) у правовідносинах самозайнята особа діє самостійно, а юридична особа вступає у правовідносини через свої органи; 3) для створення юридичної особи необхідним $є$ створення та підписання установчих документів, тоді як для набуття правового статусу самозайнятої особи установчі документи не потрібні; 4) самозайнята особа діє у правовідносинах від власного імені, яке складається з прізвища, імені та по-батькові, юридична особа має найменування, яке повинно містити інформацію про організаційно-правову форму, про характер ії діяльності; 5) місцезнаходженням самозайнятої особи може бути як іiі місце проживання, так і інша адреса, за якою з нею здійснюється зв'язок, а у юридичної особи місцезнаходженням $€$ фактичне місце ведення діяльності чи розташування офісу, з якого проводиться щоденне керування діяльністю юридичної особи; 6) на відміну від юридичної особи, правовий статус самозайнятої особи дозволяє зберігати ті права та обов'язки, які за своєю природою можуть належати лише людині, наприклад право на пенсію за віком; 7) на відміну від юридичної особи, самозайнята особа може також бути застрахованою особою, а також вступати в інші трудові правовідносини, що не пов'язані з провадженням нею підприємницької чи незалежної професійної діяльності, як працівник, крім випадків, коли такі правовідносини не обмежуються чинним законодавством.

Цікавим та актуальним є розгляд співвідношення понять самозайнятої особи та особи, яка уповноважена на виконання функцій держави, оскільки категорія «самозайняті особи» включає в себе також і осіб, які надають публічні послуги, тобто тих, яким держава у силу особливостей їхньої діяльності делегує частину своїх державновладних повноважень. Слід відзначити, що наведені поняття мають відповідний перетин у своїх обсягах. Відповідно до статті 3 Закону України «Про запобігання корупції» від 14.10.2014 № 1700-VII, до осіб, уповнова- жених на виконання функцій держави, крім інших, віднесено також осіб, які не є державними службовцями, посадовими особами місцевого самоврядування, але надають публічні послуги (аудитори, нотаріуси, приватні виконавці, оцінювачі, а також експерти, арбітражні керуючі, незалежні посередники, члени трудового арбітражу, третейські судді під час виконання ними цих функцій, інші особи, визначені законом) [4]. Таким чином, співвідношення понять «самозайнята особа» та «особа, уповноважена на виконання функцій держави» слід відобразити так: 1) наведені поняття перетинаються у своїх обсягах: серед самозайнятих осіб є особи, що уповноважені на виконання функцій держави, а серед осіб, які уповноважені на виконання функцій держави, законодавством також виділено окремі категорії самозайнятих осіб - осіб, які провадять незалежну професійну діяльність; 2) особливими правовими рисами осіб, які знаходяться на перетині зазначених вище понять, є те, що функції держави вони виконують не у зв'язку з перебуванням на посаді державної служби, роботою в органах державної влади чи місцевого самоврядування, а у зв'язку з делегуванням окремих видів державно-владних повноважень відповідно до законодавства визначеним особам, які здійснюють незалежну професійну діяльність; 3) до тих самозайнятих осіб, які уповноважені на виконання функцій держави, законодавством встановлюються спеціальні підвищені вимоги до освіти, компетенції, ділових та моральних якостей, особливостей провадження ними своєї діяльності тощо, дотримання яких забезпечується обов'язковою наявністю свідоцтва про право на зайняття відповідним видом діяльності, здійсненням державного контролю за такою діяльністю; 4) особи, які провадять незалежну професійну діяльність, що пов'язана 3 виконанням функцій держави, все ж одночасно є самозайнятими особами, які діють самостійно й організаційно незалежно, $є$ платниками податків та внесків на загальнообов'язкове державне соціальне страхування, роботодавцями (у разі необхідності), страхувальниками та застрахованими особами, виступають у правовідносинах від власного імені.

\section{Висновки}

Враховуючи викладений матеріал, слід зазначити, що зазначені нами відмінності та відповідне розмежування слугують важливим теоретичним підгрунтям для проведення подальших розробок та вдосконалення чинного законодавства. Адже натепер нечіткість нормативно-правових меж між різ- 
ними, подібними до поняття «самозайнята особа» правовими категоріями зумовлена насамперед не їхньою первинною суспільною, економічною і соціальною природою, а недосконалістю чинного законодавства. Вважаємо, що надалі чинне нормативноправове регулювання зазначеного питання повинне розвиватися у напрямі уточнення основних правових ознак поняття «самозайнята особа», кристалізації й уніфікації підходів до їі відмежування від інших подібних правових категорій, а також розробки цілісного правового інституту, який регулюватиме усі аспекти функціонування такого важливого суб'єкта правовідносин, насамперед її діяльність, як суб'єкт права соціального забезпечення.

\section{Список використаних джерел:}

1. Цивільний кодекс України : Кодекс, Закон України від 16.01.2003. № 435-IV. Голос України. 2003. № 45

2. Про державну реєстрацію юридичних осіб, фізичних осіб-підприємців та громадських формувань : Закон України від 15.05.2003 № 755-IV. Голос України. 2003. № 115.

3. Про нотаріат : Закон України від 02.09.1993 № 3425-XII. Голос України. 1993. № 198.

4. Сіроха Д. І. Фізична особа-підприємець як учасник трудових правовідносин, його поняття та характерні риси. Актуальні проблеми права: теорія іпрактика:збір. наук. праць. 2010. № 16. С. 435-441.

5. Про запобігання корупції : Закон України від 14.10.2014. № 1700-VII. Голос України. 2014. № 206.

The article focuses on improving approaches to defining the category "self-employed person" as a subject of law by identifying its most significant legal features. In the context of the above, the scientific and theoretical issues concerning the separation of the concept of "self-employed person "with other related legal categories have been updated. It is noted on the insufficient theoretical elaboration of the given concept, which causes that quite often there is an identification of the said concept with other similar normativelegal and scientific-theoretical concepts. In connection with the above author proposed his own approach to distinguishing and correlating the concept of "self-employed person" with the concepts of "natural person", "natural person-entrepreneur", "legal entity", "person authorized to perform the functions of the state". It is emphasized that, to a certain extent, similar legal characteristics of self-employed person and legal entity to be explored have similar legal characteristics. Therefore, the common legal features of the concepts of selfemployed person and legal entity are the following: both self-employed and legal entity are legal entities; both self-employed and legal entities can pursue independent and self-employed activities, at their own risk and for profit, and to fulfill a missionary mission, to achieve certain social, cultural and other goals; the acquisition of legal personality, both legal and self-employed, is connected with the state registration, as well as in certain cases with obtaining the relevant license; both self-employed and legal entities can act as an employer, be an insurer. It is concluded that for today the fuzzy boundaries of the legal and legal boundaries between different legal categories of self-employed persons are due, first of all, not to their primary social, economic and social nature, but to the imperfection of the current legislation. Further effective regulation of this issue should develop in the direction of clarification of the basic legal features of the concept of "self-employed person", crystallization and unification of approaches to distinguish it from other similar legal categories, as well as the development of a coherent legal institution that will regulate all aspects of such important functioning. relationship, and, above all, its activity as a subject of social security law

Key words: self-employed person, natural person, entrepreneur-natural person, legal entity, person authorized to perform the functions of the state, insurer. 